Journal of Research in Nursing

Vol. 1, No. 1, 2015

Print ISSN 2244-2723

University of Cebu

Cebu City, Cebu, Philippines

\title{
Needs, Barriers and Interests in Nursing Research
}

\author{
Sol Carmen N. Armecin \\ Mauro Allan P. Amparado
}

\section{Abstract}

This study determined the needs, barriers and interests of clinical instructors on faculty research at the College of Nursing, University of Cebu Banilad, Cebu City, Cebu, Philippines. The findings served as bases for a proposed faculty research program. Furthermore, the research profile of the respondents was ascertained in terms of age, civil status, gender, academic rank, length of teaching service in the college, and highest educational attainment; their level of faculty research needs; the barriers and interests in conducting faculty research; and the relationship between the profile and level of faculty research needs.

This study utilized the descriptive correlational design using a researcher-made questionnaire. The respondents were the 130 clinical instructors of the University of Cebu Banilad College of Nursing. Cronbach's alpha was used for the test-retest reliability, simple percentage and frequency for the profile of the respondents, weighted mean for the analysis of the research needs, sum of ranks for the barriers and interests, and chi-square Test of Independence to test the relationship between the profile and level of faculty research needs. 
The findings of the study revealed that majority of the respondents were 25-29 years of age, female, single, junior instructors as rank, with less than five years work service in the college, and with master's degree units. The respondents have moderate needs on the research process. The barriers to conduct faculty research are the lack of time, work load, and funding. The top research interests were health \& nutrition, poverty reduction programs, and climate change. There was a significant relationship between the respondents' length of teaching service in the college and the level of research needs.

Recommended citation: Armecin, S. C. N. \& Amparado, M. A. P. (2015). Needs, Barriers and Interests in Nursing Research. Journal of Research in Nursing, 1(1), 30-39. 